\title{
CAPITAL STRUCTURE VARIABLES OF PECKING ORDER THEORY PERSPECTIVE IN INDONESIA STOCK EXCHANGE
}

\author{
Epong Mayana I Kadek*, Anom Purbawangsa Ida Bagus \\ Economics and Business Faculty, Udayana University, Bali, Indonesia \\ *E-mail: epongmayana@gmail.com
}

\begin{abstract}
The purpose of study was to analyze variables that determine capital structure of nonfinancial companies in Indonesia based on pecking order theory. There are five variables observed namely, profitability, firm size, asset growth, asset structure, and liquidity. The population were non-financial companies listed on Indonesia Stock Exchange during 20102016 and published annual financial statements in 2009-2016. This study used census technique. Population consisted of 280 companies. Study used secondary data were data of annual financial statements during 2009-2016. Data obtained from BEl website and Indonesian Capital Market Directory. This study used multiple regression models for panel data to predict relationship between independent and dependent variables. Result showed that profitability, firm size, and asset structure had significant effect on capital structure. Other variables namely asset growth and liquidity had non-significant effect on capital structure. Study concluded that profitability is the determinant variable of capital structure on non-financial firms in Indonesia based on pecking order theory approach. The study also found that another capital structure determinant variable namely firm size and asset structure tends to follow trade-off theory.
\end{abstract}

\section{KEY WORDS}

Determinants, capital structure, Pecking Order Theory, economy.

The development of the business world in the current era of globalization requires all large- and small-scale companies to compete with each other so that they can maintain and advance the lives of their companies. The decision to choose the source of funding or the composition of the funding selection is called a funding decision (Husnan and Pudjiastuti, 2012: 277).

Corporate funding decisions, whether to use funds sourced from internal or external will be reflected in the company's capital structure. Capital structure is the mix (proportion) of the company's long-term permanent funding as indicated by debt, preferred stock equity and ordinary shares (Van Horne and Wachowicz, 2009: 452). The selection of the right capital structure will provide an opportunity for companies to improve performance, ensure the sustainability of operations and achieve strategic objectives (Hossain and Hossain, 2015). The importance of choosing a capital structure causes the factors that significantly influence it to become an important topic to study.

Research on the company's capital structure developed rapidly since the research of Franco Modigliani and Merton $\mathrm{H}$. Miller was published in 1958, which became known as MM theory (Brigham and Daves, 2017: 622). In subsequent developments Modigliani and Miller in 1963 included the tax element (Brigham and Daves, 2017: 624). With the tax, the use of debt will provide benefits in increasing the value of the company or lowering the cost of capital. After research conducted by Modigliani and Miller emerging capital structure theories, one of these theories is the pecking order theory. The pecking order theory is a capital structure theory based on the selection of funding sources based on the funding sequence put forward by Myers in 1984. According to Myers (Myers) 1984), the pecking order theory does not base assumptions on adjusting the debt level to the optimum level. The pecking order theory explains why companies with high profitability generally little debt have, not because they have a low debt ratio target but because they do not need external funds (Brealey et al., 2014: 469). 
Issuance of new shares can sometimes be very expensive and even companies prefer not to make investments that have a positive Net Present Value (NPV) just to avoid using external equity (Frank and Goyal, 2003). During 2010-2016 the sectors that had the highest debt ratios were the transportation, infrastructure and utilities sectors. The highest nonfinancial sector debt ratio in 2016 was the mining sector by $132 \%$. The lowest debt ratio is the industrial yield sector for consumption by $20 \%$. In general, from 2010-2016 the debt ratio of all sectors experienced fluctuations. In 2011 it decreased from the previous year, from $57 \%$ to $48 \%$ and then from 2012 to 2016 by $54 \%, 57 \%, 55 \%, 56 \%$ and $55 \%$. Changes in the debt ratio of non-financial companies in 2010-2016 are interesting to study, especially regarding the variables that influence them.

The selection of the right capital structure will provide an opportunity for companies to improve performance, ensure the sustainability of operations and achieve strategic objectives (Hossain and Hossain, 2015). The importance of choosing a capital structure causes the factors that significantly influence it to become an important topic to study. Based on the determinants of capital structure as previously mentioned by the researchers, there are several factors that are often examined but get different empirical results (research gap), so it is interesting to be examined again. These factors include: profitability, company size, company growth, asset structure, and liquidity.

$\mathrm{H}_{1}$ : Profitability has a negative effect on capital structure.

Profitability is the company's ability to seek profits and provides a measure of the effectiveness of the management of a company (Kasmir, 2010: 116). According to the pecking order theory, companies that have high profitability will reduce the use of debt, because high retained earnings are enough to finance most of the funding needs (Alipour et al. 2015). This statement is reinforced by the results of research conducted by Noor et al. (2015), Collins et.al (2013), Butt et al. (2013), Rakshit and Sarkar (2013) which states that profitability has a negative effect on capital structure.

$\mathrm{H}_{2}$ : Company size has a negative effect on capital structure.

Large size companies tend not to owe much because they already have large total assets. A large amount of assets has the potential to generate high profits, so the company already has sufficient internal funding to finance operational and investment needs. The amount of the company's total assets can also be used to pay off the total debt (Channar et al., 2015). Company size and capital structure have a negative effect since large companies could finance through the issuance of shares rather than debt financing, so that large companies will use less debt in the capital structure (Deloof and Overfelt, 2008). The larger the size of the company, the lower the capital structure of the company. This statement is reinforced by the results of Alipour et al. (2015), Srivastava (2014), Butt et al. (2013), Rakshit and Sarkar (2013), Akinyomi and Olagunju (2013), Rajagopal (2011), Ramlall (2009) which stated that company size had a negative effect on capital structure.

$\mathrm{H}_{3}$ : Asset growth has a positive effect on capital structure.

Companies with high asset growth require more funds in the future, especially external funds to meet their investment needs or meet the needs to finance its growth (Indrajaya et al., 2011). Capital expenditure causes a cash outflow which will increase the financing deficit (Shyam-Sunder and Myers, 1999). According to the pecking order theory, when the company's internal funds are insufficient, the company will seek external funds through debt. Pecking order theory shows a positive relationship between asset growth and debt levels (DeAngelo and Masulis, 1980; Jensen, 1986; Myers, 1984; Myers and Majluf, 1984). This statement is supported by research by Khan et al. (2015), Noor et al. (2015), Srivastava (2014), Rakshit and Sarkar (2013), Akinyomi and Olagunju (2013), Rajagopal (2011), Yuliati (2011), Ramlall (2009).

$\mathrm{H}_{4}$ : Asset structure has a negative effect on capital structure.

Companies with low levels of fixed assets have more asymmetric information problems than companies with high levels of fixed assets. Companies that have a high level of fixed assets are generally large companies, which can issue shares at a fair price so that they do not use debt to fund investment (Harris and Raviv, 1991). This statement is reinforced by the results of research conducted by Rakshit and Sarkar (2013), Çekrezi (2013), Bayrakdaroğlu 
et al. (2013), Butt et al. (2013), Saleem et al. (2013), Mahardhika and Aisjah (2012), Akinlo (2011) which stated that asset structure has a negative effect on capital structure.

$\mathrm{H}_{5}$ : Liquidity has a negative effect on capital structure.

Companies with high liquidity have large internal funds, so the company will use its internal funds first to finance its investment before using external financing through debt (Cekrezi, 2013). A company that has high liquidity means that it could pay short-term debt, so it tends to reduce total debt, which in turn capital structure will be smaller. This statement is reinforced by the results of research conducted by Alipour et al. (2015) Srivastava (2014), Rakshit and Sarkar (2013), Butt et al. (2013), Cekrezi (2013), Harrison and Widjaja (2013) which stated that liquidity has a negative effect on capital structure.

\section{METHODS OF RESEARCH}

The approach used in this research proposal is a quantitative approach (positivism) which aims to determine the relationship between two or more variables. Quantitative research approaches are research with an emphasis on testing theories through quantitative measurement of research variables using statistical analysis methods. The study was conducted at the Indonesia Stock Exchange by taking data through ICMD (Indonesian Capital Market Directory) in 2009-2016, and on the internet site www.idx.co.id. The study was conducted on non-financial companies because non-financial companies do not have rules or are more flexible, especially in funding policies. Financial companies were excluded from the analysis on the grounds of special characteristics of banking companies, namely as "regulated industry". The dependent variable in this study is the Capital Structure. The independent variables of this study are profitability, company size, asset growth, asset structure, and liquidity. This study uses panel data regression analysis method, which is a combination of time series data and cross section data (Basuki and Prawoto, 2016: 294). This research uses panel data regression analysis method. Panel data regression is a combination of time series data and cross section data (Basuki and Prawoto, 2016: 294). The method of estimating the regression model using panel data can be done through three approaches, including the Common Effect Model, the Fixed Effect Model, the Random Effect Model. Chow test and Hausman test were conducted to choose the most appropriate model to use in managing panel data. The fulfillment of the classical assumption test for panel data regression was measured only by the multicollinearity test and the heterokedasticity test (Basuki and Prawoto, 2016: 298). The t test statistic and the F test are used to test the research hypothesis, namely how much influence the independent variable has on the dependent variable can be determined by the analysis of the coefficient of determination.

\section{RESULTS AND DISCUSSION}

Determining the selection of panel data regression models two types of testing need to be done. The first test will be a Chow test to determine the choice between a pool / common effect model or a fixed effect model. In the next stage the Hausman test will be carried out if necessary. Table 1 shows the cross-section $F$ probability value of 0,000 which is less than 0.05. Based on the results of the Chow test, it can be decided that $\mathrm{HO}$ is rejected, so it can be stated that the fixed effect model is better than the common effect model.

After the Chow test, the Hausman test is then necessary to determine whether the regression model is more suitable to follow the fixed effect model or random effect model. Table 2 shows the random cross-section probability value of 0.0000 which is smaller than 0.05 . Based on these results, $\mathrm{HO}$ is rejected, so it can be stated that with a $95 \%$ confidence level, the fixed effect model is more suitable for use in panel data regression.

Multicollinearity test can be done by calculating the correlation coefficient between independent variables. If the correlation coefficient is low, there is no multicollinearity problem. Table 3 shows that the correlation coefficient values for all independent variables are smaller than 0.80. Based on the data in table 4, it can be stated that there is no multicollinearity problem or there is no linear relationship between the independent variables. 
Table 1 - Chow Test Result

Redundant Fixed Effects Tests

Pool:DATA_KEUANGAN

Test cross-section fixed effects

\begin{tabular}{llll}
\hline \hline Effects Test & Statistic & d.f. & Prob. \\
\hline \hline Cross-section F & 12.531692 & $(279,1675)$ & 0.0000 \\
Cross-section Chi-square & 2209.545424 & 279 & 0.0000 \\
\hline
\end{tabular}

Source: Data Processed, 2018.

Table 2 - Hausman Test Result

Correlated Random Effects - Hausman Test

Pool:DATA_KEUANGAN

Test cross-section random effects

Test Summary

Chi-Sq. Statistic

Chi-Sq. d.f.

Prob.

Cross-section random

33.023286

5

0.0000

Source: Data Processed, 2018.

Table 3 - Multicollinearity Test Results

\begin{tabular}{|c|c|c|c|c|c|c|}
\hline Independent Variable & DER & PRO & SIZE & GRO & SA & LIQ \\
\hline DER & 1.000000 & -0.232625 & 0.209882 & -0.024804 & 0.209293 & -0.113081 \\
\hline PRO & -0.232625 & 1.000000 & 0.135938 & -0.005004 & -0.104253 & -0.048026 \\
\hline SIZE & 0.209882 & 0.135938 & 1.000000 & 0.012966 & -0.011093 & -0.092076 \\
\hline GRO & -0.024804 & -0.005004 & 0.012966 & 1.000000 & -0.037532 & 0.181830 \\
\hline SA & 0.209293 & -0.104253 & -0.011093 & -0.037532 & 1.000000 & -0.090479 \\
\hline LIQ & -0.113081 & -0.048026 & -0.092076 & 0.181830 & -0.090479 & 1.000000 \\
\hline
\end{tabular}

Source: Data Processed, 2018.

Park test was conducted to determine whether there is a heteroscedasticity problem. Basic decision making is done by comparing the probability value (prob) with 0.05 (confidence level or $\alpha$ of $5 \%$ ). Table 5 shows that the probability value (prob) of all independent variables is greater than 0.05 , so in this model there is no heteroscedasticity problem.

Table 4 - Park Test Result

\begin{tabular}{lllll}
\hline \hline Variable & Coefficient & Std. Error & t-Statistic & Prob. \\
\hline \hline C & -4.072313 & 1.690082 & -2.409536 & 0.0161 \\
PRO & -0.989926 & 0.736091 & -1.344843 & 0.1789 \\
SIZE & -0.131719 & 0.114294 & -1.152460 & 0.2493 \\
GRO & 0.000110 & 0.005261 & 0.020921 & 0.9833 \\
SA & 0.936236 & 0.505056 & 1.853726 & 0.0640 \\
LIQ & 0.004849 & 0.003504 & 1.383974 & 0.1666 \\
\hline \hline
\end{tabular}

Source: Data Processed, 2018. 
Based on the results of the panel data regression model selection through the Chow test and the Hausman test that had been done previously, the panel data regression analysis used the fixed effect model approach. The results of panel data regression using the fixed effect approach can be seen in table 5.

Table 5 - Regression Test Results with Fixed Effect Model

\begin{tabular}{lllll}
\hline \hline Variable & Coefficient & Std. Error & t-Statistic & Prob. \\
\hline \hline C & -0.596585 & 0.190371 & -3.133805 & 0.0018 \\
PRO & -0.312846 & 0.082913 & -3.773164 & 0.0002 \\
SIZE & 0.076280 & 0.012874 & 5.925087 & 0.0000 \\
GRO & -0.001024 & 0.000593 & -1.727759 & 0.0842 \\
SA & 0.254626 & 0.056890 & 4.475792 & 0.0000 \\
LIQ & -0.000562 & 0.000395 & -1.423570 & 0.1548 \\
\hline \hline
\end{tabular}

Effects Specification

Cross-section fixed (dummy variables)

\begin{tabular}{llll}
\hline \hline R-squared & 0.726421 & Mean dependent var & 0.577644 \\
Adjusted R-squared & 0.680035 & S.D. dependent var & 0.419599 \\
S.E. of regression & 0.237348 & Akaike info criterion & 0.095104 \\
Sum squared resid & 94.35932 & Schwarz criterion & 0.906583 \\
Log likelihood & 191.7984 & Hannan-Quinn criter. & 0.393366 \\
F-statistic & 15.66039 & Durbin-Watson stat & 1.105942 \\
Prob(F-statistic) & 0.000000 & & \\
\hline \hline
\end{tabular}

Source: Data Processed, 2018.

Table 6 shows the constant value $(C)$ of -0.596585 while the coefficients of PRO, SIZE, GRO, SA, and LIQ are respectively $-0.312846 ; 0.076280 ;-0.001024 ; 0.254626$; and $-0,000562$ with a significance level of five percent. Then the regression equation can be arranged as follows:

DER $=-0,596585-0,312846$ PRO $+0,076280$ SIZE - 0,001024GRO + 0,254626SA -0,000562LIQ

The study uses Adjusted $R$ Square value because the value of $R$ Square in the regression equation is vulnerable to the addition of independent variables, where the more independent variables involved, the greater the value of $\mathrm{R}$ Square (Basuki and Prawoto, 2016: 51). Adjusted $R$ Square value of 0.680035 , meaning that the independent variable is profitability, company size, asset growth, asset structure and liquidity can explain the dependent variable that is the capital structure of $68.00 \%$, while the remaining $32.00 \%$ is explained by other variables not found in research.

According to Basuki and Prawoto (2016: 51), the F test in multiple linear regression analysis aims to determine the effect of the independent variables on the dependent variable simultaneously. The test criteria is if the probability value (F-statistic) is greater than 0.05 
(confidence level or $\alpha$ of $5 \%$ ) then $\mathrm{HO}$ is accepted while if the probability value (F-statistic) is less than 0.05 then $\mathrm{H} 1$ is accepted. Based on table 5 the probability value (F-statistic) of 0.0000 shows that the independent variable, namely profitability, company size, asset growth, asset structure and liquidity, has a significant effect on the dependent variable, which is capital structure simultaneously. According to Basuki and Prawoto (2016: 52), the t test was used to determine the effect of each independent variable on the dependent variable partially. The test criteria is if the probability value is greater than 0.05 (confidence level or $\alpha$ of $5 \%$ ) then $\mathrm{HO}$ is accepted while if the probability value is less than 0.05 then $\mathrm{H} 1$ is accepted.

Table 6 - Individual Effect Regression Fixed Effect Model Results

\begin{tabular}{|c|c|c|c|c|c|}
\hline Fixed Effects (Cross) & Coeficient & Fixed Effects (Cross) & Coeficient & Fixed Effects (Cross) & Coeficient \\
\hline AALI--C & -0.356488 & AKRA--C & -0.077887 & ASGR--C & -0.239983 \\
\hline ABBA--C & 0.394172 & ALKA--C & 0.145429 & ASII--C & -0.28239 \\
\hline ACES--C & -0.255553 & ALMI--C & -0.053057 & ASRI--C & 0.338891 \\
\hline _ADES--C & 0.256927 & AMFG--C & -0.278956 & ATPK--C & -0.04015 \\
\hline ADHI--C & 0.135715 & AMRT--C & -0.023627 & AUTO--C & -0.408077 \\
\hline ADMG--C & -0.06592 & ANTM--C & -0.174624 & BAPA--C & 0.199727 \\
\hline ADRO--C & 0.065294 & APLI--C & -0.219346 & BATA--C & -0.235818 \\
\hline AISA--C & 0.149213 & APLN--C & 0.202065 & BAYU--C & -0.197895 \\
\hline AKKU-C & 0.818376 & ARNA-C & -0.246475 & BCIP--C & 0.013582 \\
\hline AKPI--C & 0.047439 & ARTI--C & 0.050739 & BHIT--C & -0.112649 \\
\hline
\end{tabular}

Source: Data Processed, 2018.

Table 6 shows the results of individual regression for 30 samples. The fixed effect approach in the research method shows that there are different effects between individuals (Basuki and Prawoto, 2016: 279). Although the intercepts of each sample are different, the intercepts of each sample are not different at any time. Table 6 shows the intercepts of each sample in sequence for AALI, ABBA and ACES of $-0.31285 ; 0.07628$ and-0.00102. The intercept values reflect the specific characteristics of each company. Each sample company has a different policy in determining capital structure.

Table 7 - Hypothesis Test Results

\begin{tabular}{llllll}
\hline No. & Variable Independent & Coefficient & Sig. & Pecking Order Theory Hypothesis & Test Result \\
\hline 1 & Profitability & -0.31285 & 0.0002 & $(-)$ & $(-)$ Significant \\
2 & Company Size & 0.07628 & 0 & $(-)$ & $(+)$ Significant \\
3 & Asset Growth & -0.00102 & 0.0842 & $(+)$ & $(-)$ Not Significant \\
4 & Asset Structure & 0.254626 & 0 & $(-)$ & $(+)$ Significant \\
5 & Liquidity & -0.00056 & 0.1548 & $(-)$ & $(-)$ Not Significant \\
\hline
\end{tabular}

Source: Data Processed, 2018.

Table 7 shows the probability value of the GRO, and LIQ variables of 0.0842 and 0.1548 greater than 0.0 . These results indicate that the independent variables consisting of asset growth and liquidity do not significantly affect capital structure. The probability value of the PRO, SIZE and SA variables is $0.0002 ; 0.0000$ and 0.0000 smaller than 0.05 . These results indicate that the variable profitability, company size and asset structure significantly influence the capital structure. A summary of the results of hypothesis testing can be seen in Table 7

Table 7 shows that the profitability variable that is proxied by ROA negatively significantly affects the capital structure. The results are in line with the pecking order theory which states that profitability has a negative effect on capital structure. Companies with high profitability will increase the company's retained earnings. High retained earnings require large internal funding sources. High retained earnings are enough to finance most of the company's funding needs, so the company will reduce the use of debt. The results are in accordance with previous studies by Pacheco and Tavares (2016), Chadha and Sharma 
(2015), Khan et al. (2015) and Noor et al. (2015) which confirms the pecking order theory, that profitability has a significant negative effect on capital structure.

Table 7 shows that firm size variables have a significant positive effect on capital structure. The results of the study are not in line with the pecking order theory, but in accordance with the assumption of a trade-off theory in which large sector companies have large capital structures because they use more debt. Large companies are better at using debt to finance their operations because they have the ability to diversify risk and minimize bankruptcy. Large companies are also easier to obtain loans from creditors, because they have large assets that can be used as collateral to obtain debt. The results of the study are in line with previous research by Qaderi et at. (2015), Wardianto (2013), Nuswandari (2013), Collins et at. (2013), Cekrezi (2013).

Table 7 shows that the growth of company assets negatively does not significantly affect capital structure. The results are not in line with the pecking order theory but in accordance with the trade-off theory in which non-financial sector companies that have high asset growth owe less than companies that have low asset growth. Companies with high asset growth tend to have higher profits. Large amount of profits will be used to finance operational activities and investments so that the level of debt becomes lower. The results of the study are in line with previous studies by Qaderi et at. (2015), Nuswandari (2013), Wardianto (2013), Saleem et al. (2013), Akinio (2011), Ali (2011).

Table 7 shows that asset structure has a significant positive effect on capital structure, which means that the higher the asset structure of the company, the higher the capital structure will be. Non-financial sector companies in Indonesia in the period 2010-2016 with large asset structures are more easily indebted, because companies can use more fixed assets as collateral. The results of the study are not in line with the pecking order theory which states that there is a negative relationship between asset structure and capital structure. Companies with low levels of fixed assets have more asymmetric information problems than companies with high levels of fixed assets. Companies with a high level of fixed assets are generally large companies, these companies can issue shares at a fair price so that debt is not used to finance investment. In contrast, the results of the study confirm the trade-off theory which states that asset structure has a significant positive effect on capital structure, and is in line with previous research by Chadha and Sharma (2015), Qaderi et al. (2015), Alipour et al. (2015), Khan et al. (2015).

Table 7 shows that liquidity has a significant negative effect on capital structure. The results confirm the pecking order theory where high liquidity reflects the company already has cash flow or high internal funding sources. High internal funding is enough to finance the company's operations, so that it will reduce the use of debt. Liquidity shows the company's ability to meet short-term obligations. High liquidity of the company means that the company is able to pay long-term debt that is due without having to use sources of long-term financing. Empirical evidence of the research is in line with research by Haron (2016), Pacheco and Tavares (2016), Alipour et al. (2015), Srivastava (2014), Rakshit and Sarkar (2013), Butt et al. (2013), Cekrezi (2013), Harrison and Widjaja (2013), Hestuningrum and Darsono (2012), Sheikh and Wang (2011).

Based on the results of the study, there are three variables that significantly influence the capital structure, namely profitability, company size and asset structure. The other two variables namely asset growth and liquidity do not significantly influence the capital structure. The study found that profitability is a determinant variable of capital structure based on the pecking order theory. The study also found the determinants of capital structure based on the trade-off theory, namely company size and asset structure. The use of panel data regression with fixed effect mode is able to emphasize that each company is considering different capital structures. Each company considers the selection of funding sources based on the order of funding, namely internal sources first (pecking order theory). But there are also conditions for companies trying to balance benefits and costs as a result of debt (trade-off theory). 


\section{CONCLUSION}

Some conclusions can be obtained from the results of data analysis and discussion. First, profitability negatively significantly influences capital structure. Second, company size positively significantly influences capital structure. Third, the growth of company assets negatively does not significantly affect the capital structure. Fourth, the asset structure has a significant positive effect on capital structure. Fifth, liquidity has no significant negative effect on capital structure. Sixth, companies in implementing funding policies do not absolutely follow the rules of the pecking order theory, but also follow the rules of other capital structure theories.

Suggestions that can be given are: First, for companies in making funding decisions pay attention to factors that have a significant impact on capital structure in this study, namely profitability, company size and asset structure. Second, it is recommended for further researchers to add other variables or use the same variable with different proxies.

\section{REFERENCES}

1. Ali, Liaqat. 2011. The Determinants of Leverage of the Listed-Textile Companies in India,European Journal of Business and Management, Vol.III, No.12, pp.54-90.

2. Akinyomi, O.J And Adebayo,O.2013. Determinants of Capital Structure in Nigeria,International Journal of Innovation and Applied Studies, Vol. III, No. 4, pp. 9991005.

3. Alipour, Mohammad. Mohammadi, M. F.S. Derakhshan,H. 2015. Determinants of Capital Structure: An Empirical Study of Firms In Iran.International Journal of Law and Management, Vol.LVII, No. 1, pp. 53-83.

4. Akinlo, Olayinka. 2011. Determinants of capital structure: Evidence from Nigerian panel data, African Economic and Business Review, Vol.IX, No. 1, pp. 1-16.

5. Basuki. Agus T, dan Prawoto. 2016. Analisis Regresi dalam Penelitian Ekonomi dan Bisnis. Jakarta: Raja Grafindo Persada.

6. Bayrakdaroglu, A. Ege, I. and Yazici, N. 2013. A Panel Data Analysis of Capital Structure Determinants: Empirical Results from Turkish Capital Market, International Journal of Economics and Finance, Vol. V, No. 4, pp. 131-140.

7. Bharath, S. T, Paolo.P,Guojun,W. 2009. Does Asymmetric Information Drive Capital Structure Decisions?,The Review of Financial Studies, Vol. XXII, No. 8, pp. 3212-3243.

8. Brealey, R.A., Myers, S.C., and Allen, F. 2014. Principles of Corporate Finance, $10^{\text {th }}$ Edition. New York: Mc-Graw Hill.

9. Brigham, Eugene F, and Daves, P. 2017. Intermediate Financial Management, $12^{\text {th }}$ Edition. South Western: Cengage Learning.

10. Brigham, Eugene F. dan Ehrhardt, Michael. 2011.Financial Management:Theory and Practice.Edisi 11. Jakarta: Salemba Empat.

11. Brigham, Eugene F. dan Houston, Joel F. 2011.Dasar-dasar Manajemen Keuangan Terjemahan.Edisi 13. Jakarta: Salemba Empat.

12. Butt, S.Zeeshan,A.K.Bilal, N. 2013. Static Trade-Off Theory or Pecking Order Theory Which One Suits Best To The Financial Sector. Evidence from Pakistan, European Journal of Business and Management, Vol.V, No.23, pp.131-140.

13. Cekrezi, Anila. 2013. The Determiants of Capital Structure: A case of Small non-traded Firms in Albania. Proceeding $1^{\text {st }}$ Global Virtual Conference,April 2-12, 2013.

14. Chadha,S. and Sharma, A.K. 2015. Determinants of Capital Structure: an Empirical Evaluation, Journal of Advances in Management Research, Vol. XII, No.1, pp. 3-14.

15. Channar, A. Manisha, B.M. Piribhat,A. 2015. Determinants of Capital Structure of Service And Manufacturing Sectors of Pakistani Companies Listed In Karachi Stock Exchange, JournalBusiness Review, Vol. X, No.1, pp.72-85.

16. Collins, S.O. Clement, A.A. and Funke, A.R. 2013. Profitability and Debt Capital Decision: A Reconsideration of the Pecking Order Model,International Journal of Business and Management, Vol.8, No. 13, pp.24-34. 
17. DeAngelo, H. and Masulis, R.W. 1980. Optimal Capital Structure under Corporate and Personal Taxation, Journal of Financial Economics, No. 8, pp. 3-29.

18. Delcoure, Natalya.2007.The Determinants Of Capital Structure In Transitional Economies, International Review of Economics \& Finance, Vol.16, No.3, pp. 400-415.

19. Deloof, Marc and Wouter Van Overfelt. 2008. Were Modern Capital Structure Theories Valid inBelgium before World War I? Journal of Business Finance \& Accounting, Vol. XXXV, No. 3, pp. 491-515.

20. Dereeper, S. and Trinh, Q.D. 2015. Trade-off Theory of Pecking Order Theory with a State-Ownership Structure: The Vietnam Case, International Review of Business Research Papers, Vol. XI, No. 1, pp. 114-132.

21. Fama, E.F. \& French, K.R.2002. Testing Trade-Off and Pecking Order Predictions About Dividends and Debt. The Review of Financial Studies, Vol. XV, No.1, pp.1-33.

22. Ferry, M.G., dan Jones, W.H. 1979. Determinants of Financial Structure: A New Methodological Approach. The Journal of Finance, Vol.XXXIV, No.3, pp.631-644.

23. Frank, M.Z. and Goyal, V.K.2003. Testing the Pecking Order Theory of Capital Structure, Journal of Financial Economics, Vol. LXVII, pp. 217-248.

24. Frank, Murray. and Vidhan K. Goyal, 2009. Capital structure decisions: Which factors are reliably important?"' Financial Management, Vol.XXXVIII, pp.1-37.

25. Haron, Razali. 2016. Do Indonesian Firms Practice Target Capital Structure? A Dynamic Approach", Journal of Asia Business Studies, Vol. X, No.3, pp. -

26. Harris, M. and Raviv, A. 1991. The Theory of Capital Structure, The Journal of Finance, Vol. XLVI, No. 1, pp. 297-355.

27. Harrison, Barry. and Theodorus,W.W.2013. Did The Financial Crisis Impact on The Capital Structure of Firms?,Nottingham Trent University. (online), (http//www.ntu.ac.uk/ nbs/document_uploads/151944.pdf).

28. Hestuningrum,R.D. dan Darsono. 2012. Pengaruh Karakteristik Perusahaan Terhadap Struktur Modal Perusahaan Pemanufakturan Yang Terdaftar Pada Bursa Efek Indonesia, Diponegoro Journal of Accounting, Vol. I, No.1, hal.1-12 .

29. Hossain, Imran and Hossain, Akram.2015.Determinants of Capital Structure and Testing of Theories: A Study on the Listed Manufacturing Companies in Bangladesh, International Journal of Economics and Finance, Vol. VII, No. 4.

30. Husnan dan Pudjiastuti.2012. Dasar-Dasar Manajemen Keuangan. Edisi 6.Yogyakarta: UPP STIM YKPN.

31. Indrajaya, G.Herlina.Rini, S. 2011. Pengaruh Struktur Aktiva, Ukuran Perusahaan, Tingkat Pertumbuhan, Profitabilitas dan Risiko Bisnis Terhadap Struktur Modal: Studi Empiris Pada Perusahaan Sektor Pertambangan yang Listing di Bursa Efek Indonesia Periode 2004-2007, Jurnal Ilmiah Akuntansi, No. 06, hal.1-23.

32. Jensen, M.C. 1986. Agency Cost of Free Cash Flow, Corporate Finance and Takeovers, American Economic Review, Vol. LXXVI, No. 2, pp. 323-329.

33. Joni dan Lina. 2010. Faktor-Faktor yang Mempengaruhi Struktur Modal, Jurnal Bisnis dan Akuntansi. Vol.XII, No.2, hal.81-96.

34. Kasmir. 2010. Pengantar Manajemen Keuangan. Jakarta:Kencana.

35. Kallapur, S. and Trombley, M.A. 1999. The Association between Investment Opportunity Set Proxies and Realized Growth, Journal of Business Finance and Accounting, Vol.XXVI, No. 4, pp. 505-519.

36. Khan, Ishtiaq. Saeed,U.J, Mushtaq,K. 2015.Determinant of Capital Structure: An Empirical Study of Cement Sector of Pakistan, Asian Journal of Management Sciences \& Education, Vol. IV, No.3, pp.50-60.

37. Kuhnhausen.F, and Stieber.H. 2014. Determinants of Capital Structure in Non-Financial Companies. Managerial Finance, Vol. XXXVII, No. 2, pp. 117-133.

38. Mahardhika, B.P. dan Aisjah. 2012. Pengujian Pecking Order Theory Dan Trade Off Theory Pada Struktur Modal Perusahaan (Studi Pada Perusahaan Consumer Goods Di Bursa Efek Indonesia), Jurnal IImiah Mahasiswa FEB UB, Vol. II, hal.1-11. 
39. Matusin. A. R., Andryan. R., Pamela. A. 2014. The Impact Capital Structure on Agency Costs of Indonesian Listed Companies. International Conference on Bussiness, Economics and Accounting March 26-28, 2014, Hongkong.

40. Munawir, Slamet. (2010). Analisa Laporan Keuangan.Yogyakarta: Liberty.

41. Myers, S.C. 1984. The Capital Structure Puzzle, The Journal of Finance, Vol. XXXIX, No.3, pp.575-592.

42. Myers, S.C. and Majluf, N.S. 1984. Corporate Financing And Investment Decisions When Firms Have Information That Investors Do Not Have,Journal of Financial Economics, No.13, pp.187-221.

43. Noor, Tajudin. Bonar, S. Nur A.M.T.B.2015. Testing On Pecking Order Theory And Analysis Of Company's Characteristic Effects on Emitten's Capital Structure, Indonesian Journal of Business and Entrepreneurship, Vol. I, No.2, pp. 1-9.

44. Nuswandari, Cahyani. 2013. DeterminanStruktur Modal DalamPerspektifPecking Order Theory Dan Agency Theory, Dinamika Akuntansi, Keuangan Dan Perbankan, Vol. II, No. 1, hal.92 - 102.

45. Pacheco, L. and Tavares,F.2015.Capital Structure Determinants of Portuguese Footwear Sector SMEs: Empirical Evidence Using a Panel Data, Review of Applied Management Studies, Vol. I, No. 13, pp. 145-157.

46. Pattweekongka, S. and Napompech, K. 2014. Determinants of Capital Structure: Evidence from Thai Lodging Companies, International Journal of Arts and Sciences, Vol. XII, No, 4, pp. 45-52.

47. Qaderi,B. Peyman,R. Sabah,B. Saeid,H.2015.Impact of Firm Specific Factors on Capital Structure Decision: Evidence from Iranian Listed Companies,Academic Journal Of Research In Business And Accounting, Vol. III, No. 2, pp. 1-10.

48. Rajagopal, S. (2011). The Portability of Capital Structure Theory: Do Traditional Models Fit In An Emerging Economy?, Journal of Finance and Accountancy, Vol. V, No.1, pp. 117.

49. Rajan.R.G and Zingales.L.1995. What Do We Know About Capital Structure? Some Evidence from International Data. The Journal of Finance, Vol.L, No.5, pp. 1421-1460.

50. Rakshit, D. and Sarkar, T.2013. Determinants of Capital Structure of Selected Companies From Cement Industry In India:A Case Study, International Journal of Research in Management \& Social Science,Vol.I No. 4, pp.29-38.

51. Ramlall, Indranarain.2009. Determinants of Capital Structure Among NonQuotedMauritian Firms Under Specificity of Leverage: Looking for a Modified Pecking Order Theory, International Research Journal of Finance and Economics, Vol.31,pp. 8492.

52. Ross, S.A. 1977. The Determination of Financial Structure: The Incentive-Signaling Approach, The Bell Journal of Economics, Vol. VIII, No. 1, pp.23-40.

53. Ruslim, Herman.2009. Pengujian Struktur Modal (TeoriPecking Order): Analisis Empiris Terhadap Saham Di LQ-45.JurnalBisnis Dan Akuntansi,Vol. XI, No. 3,hal.209-221.

54. Sabir, M.and Malik,Q.A. 2012. Determinants of Capital Structure - A Study of Oil And Gas Sector of Pakistan, Interdisciplinary Journal of Contemporary Research In Business, Vol.III, No.10, pp.395-400.

55. Saleem,F.Bisma,R. Qaiser,M. 2013. The Determination of Capital Structure of Oil And Gas Firms Listed on Karachi Stock Exchange In Pakistan, Interdisciplinary.Journal Of Contemporary Research In Business, Vol. IV, No. 9,pp.225-235.

56. Sheikh, Jibran. Shakeel, AW. Iqbal, W. Tahir,M.M.2012. Pecking at Pecking Order Theory: Evidence from Pakistan's Non-financial Sector,Journal of Competitiveness, Vol.IV, No.4, pp.86-95.

57. Sheikh, N. A. and Wang, Z. 2011. Determinants of Capital Structure: An Empirical Study of Firms in Manufacturing Industry of Pakistan, Managerial Finance, Vol. XXXVII, No. 2, pp. 117-133.

58. Srivastava, Namita. 2015. Determinants of leverage of Indian companies: An empirical analysis (A study of Cement Industry in India), Journal of Art, Social Science and Humanities, Vol. II, No.2, pp. 21-24. 
59. Shyam-sunder, L. \& Myers, S.C., 1999. Testing Static Trade-off Against Pecking Order Models of Capital Structure,Journal of Financial Economics, Vol. LI, pp.219-244.

60. Titman, S. and Wessels, R. 1988. The Determinants of Capital Structure Choice, the Journal of Finance, Vol. XLIII, No.1, pp. 1-19.

61. Van Horne dan Wachowicz.2009. Fundamental of Financial Management: Prinsip-Prinsip Manajemen Keuangan. Edisi 12. Jakarta: Salemba Empat .

62. Viviani, J.L. 2008. Capital Structure Determinants: An Empirical Study of French Companies in the Wine Industry, International Journal of Wine Business Research, Vol. XX, No. 2, pp. 171-194.

63. Wardianto, K.B.2013. Pengujian Pengujian Pecking Order theory Pada Non-Bank Financial Institution (NBFIs) Di Indonesia, Jurnal Perspektif Bisnis, Vol.I, No.1, hal. 33-44.

64. Widarjono, A .2013. Ekonometrika: Pengantar dan aplikasinya, Jakarta: Ekonosia.

65. Yuliati, S.2011. Pengujian Pecking Order Theory: Analisis Faktor- Faktor Yang Mempengaruhi Struktur Modal Industri Manufaktur Di BEl Periode Setelah Krisis Moneter,Jurnal Politeknosains, X(1), hal.56-69. 